\title{
CYCLOOXYGENASE 2: UNDERSTANDING THE PATHOPHYSIOLOGICAL ROLE THROUGH GENETICALLY
}

ALTERED MOUSE MODELS

Paloma Martín Sanz ${ }^{1,2}$, Sonsoles Hortelano ${ }^{2}$, Lisardo Boscá ${ }^{1,2}$ and Marta Casado ${ }^{3}$

${ }^{1}$ Centro de Investigaciones Biológicas CIB (CSIC), ${ }^{2}$ Centro Nacional de Investigaciones Cardiovasculares (CNIC). Melchor Fernández Almagro 3, 28029 Madrid (Spain); ${ }^{3}$ Instituto de Biomedicina de Valencia (CSIC) Jaime Roig 11, 46010 Valencia (Spain)

\section{TABLE OF CONTENTS}

1. Abstract

2. Introduction

3. Insight into the physiological roles of COX-2 through genetically altered mice

3.1. Kidney

3.2. Gastrointestinal tract

3.3. Reproduction

3.4. Brain

3.5. Cardiovascular system

3.6. Liver

4. COX-2 in pathological states

4.1. Inflammation

4.2. Tumorigenesis

4.2.1. Gastric and intestinal tumors

4.2.2. Breast cancer

4.2.3. Skin carcinogenesis

4.2.4. Hepatocellular carcinoma (HCC)

5. Summary and Perspectives

6. Acknowledgement

7. References

\section{1. - ABSTRACT}

Cyclooxygenase (COX) -1 and -2 catalyze the first step in the biosynthesis of prostanoids. COX-1 is constitutively expressed in many tissues and seems to be involved in the house keeping function of prostanoids. COX-2, the inducible isoform, accounts for the elevated production of prostaglandins in response to various inflammatory stimuli, hormones and growth factors. COX-2 expression has been also associated with cell growth regulation, tissue remodelling and carcinogenesis. More of these characteristics have been elucidate through using COX selective inhibitors. Recent advances in transgenic and gene-targeting approaches allow a sophisticated manipulation of the mouse genome by gene addition, gene deletion or gene modifications. The development of COX-2 genetically altered mice has provided models to elucidate the physiological and pathophysiological roles of this enzyme.

\section{2. - INTRODUCTION}

Prostaglandins (PGs) and thromboxanes (TXs), potent bioactive lipid messengers collectively known as prostanoids, are implicated in many physiological processes including platelet aggregation, maintenance of the gastric mucosa integrity and reproduction. In addition to these physiological effects, these prostanoids are regulators of inflammation, fever and pain and play an important role in the pathogenesis of cancer. The biosynthesis of prostanoids occurs in three steps: (i) liberation of arachidonic 
acid (AA) from membrane phospholipids by the action of phospholipase enzymes; (ii) the formation of PG endoperoxide $\mathrm{H}_{2}$ $\left(\mathrm{PGH}_{2}\right.$ ) from AA mediated by a prostaglandin G/H synthase (EC 1.14.99.1), also known as cyclooxygenase (COX) and (iii) the conversion of $\mathrm{PGH}_{2}$ to a specific prostanoid through the action of specific prostaglandin and thromboxane synthases (figure 1) (1). After prostanoids exited the cells via a carried mediated process, they activate prostanoids-dependent G protein-linked receptors (2) and nuclear receptors of the peroxysome proliferators-activating receptor family (PPARs) (3).

Two isoforms of cyclooxygenase, COX-1 and COX-2, are known. COX-1 is constitutively expressed in many tissues and seems to perform housekeeping functions; by contrast, COX-2 is undetectable in most tissues except placenta, testes, macula densa of the kidney and brain. Nevertheless, COX-2 is rapidly induced in response to various inflammatory stimuli, hormones and growth factors, and has consequently been referred to as the "inducible” isoform (4). However, genetic and pharmacological studies in rodents suggest that both isoforms may be important in maintaining physiological homeostasis and contribute to the inflammatory response and carcinogenesis. Therefore, the designations as housekeeping and/or response gene may not be entirely accurate (5).

COX isoenzymes were found to be approximately 600 aminoacids in size in all species. They share $61 \%$ primary sequence identity and have similar kinetics properties with minimal differences. It has been suggested that low concentrations of AA $(<2.5 \mu \mathrm{M})$ are oxygenated exclusively by COX-2 in intact cells (6). It was proposed that both proteins prefer separate pools of arachidonic acid by using different phospholipases (7). However, recent studies demonstrated that PGs production via COX-2 in activated cells is not controlled by specific coupling between phospholipases and COXs (8).

The structures of COX-1 and COX-2 predict that both enzymes are located in the lumen of nuclear envelope and the endoplasmic reticulum. However, several authors have revealed other localizations of COX-1 (lipid bodies) and COX-2 (caveolin-1-containing vesicles). The physiological significance of the extraluminal localizations is current unknown (9).

The COX-1 promoter region lacks a canonical TATA or CAAT box and is GC rich, features consistent with those of a housekeeping gene. Despite this, COX-1 is inducible in some cells like in endothelia in response to different stimuli $(10,11)$. On the other hand, there are many consensus cis-elements in the 5' flanking region regulating the transcription of COX-2 gene, including a TATA box. Among them, CRE, NF-IL6 motifs, NF-kappaB site and the E-box are known to be involved in the regulation of COX-2 gene expression (4). Recently, several authors have shown the importance of NFAT and AP-1 sites in the induction of COX-2 expression upon several stimuli, including phorbol ester PMA/calcium ionophore treatment in tumoral cells (12), vascular endothelial growth factor in vascular endothelial cells (13) or endothelin-1 in rat glomerular mesangial cells (14).

The cyclooxygenases are the pharmacological targets of non-steroidal anti-inflammatory drugs (NSAIDs). Ever since in 1971 Vane first reported the mechanism of action for aspirin-like drugs (15), NSAIDs with varying of isoform specificity have been developed (9). Much our current understanding about the physiological roles of COX-2 has been obtained from studies with NSAIDs. However, it has been identified non-COX-2 targets of NSAID action, reason why the effects observed with these agents may not always reveal the physiological roles of COX isoforms (16-18). To better characterize the physiological and pathological functions of COXs, a number of genetically engineered mouse models have been generated. This review will be focused in the contribution of the transgenic animal models to the study the roles of COX-2 in normal and diseased states. 
Both the "gain of function" (transgenesis) and "loss of function” (gene targeting) of individual genes have been utilized for stable modification of the mouse genome, providing powerful experimental systems to study pathophysiology. Transgenesis is mainly achieved by microinjection of the transgenic construct into the pronucleus of 1-cell embryos, which are subsequently implanted into pseudopregnant female mice. In the gene-targeting approach, a gene of interest is replaced with a mutated sequence in embryonic stem cells via homologous recombination. The targeted ES cells are microinjected into blastocysts that are then implanted into receiving females (figure 2) (19).

In spite of the modest number of animal models that constitutively express COX-2, the transgenic mice have provided valuable insight into the COX-2 contribution to tumorigenesis (20-23).

COX knockout models have been profoundly studied. All COX-deficient mice, including the double COX-1/COX-2 knockout mice, are produced in the expected Mendelian ratio, indicating that in mice, embryo implantation and survival in utero does not require fetal PG synthesis (24-27). COX-2 knockout animals lacked the respective normal size message and protein and nor did appear to upregulate the expression of COX-1. Mice deficient in both isoforms are born alive but they die during the first day of life because the ductus arteriosus fails to close after birth. For COX-2-deficent mice that are either wild-type or heterozygous for the COX-1 gene, neonatal mortality is 35 or $79 \%$, respectively. These findings indicate that the PG synthesis required for normal closure of the ductus arteriosus depends primarily on COX-2, although COX-1 provides partial compensation in mice deficient in COX-2.

\section{INSIGHT INTO THE PHYSIOLOGICAL ROLES OF COX-2 THROUGH GENETICALLY ALTERED MICE}

\subsection{Kidney}

The kidney is a tissue rich in PG synthesis. Several studies have looked at the importance of COX-2 in renal pathophysiology. In a rat model of glomerulonephritis involving mesangiolysis, the selective inhibition of COX-2 impaired glomerular capillary repair (28). In patients with active lupus nephritis, both renal and systemic COX-2 was upregulated (29). In other models of renal injury such as the remnant kidney, renovascular hypertension and diabetes, increased COX-2 renal expression has also been detected [see (30) for review]. But, it has only been possible to identify a prominent role for COX-2 in both the development and function of the kidney through the characterization of COX-2 knockout model.

One of the most striking findings in the mice lacking the COX-2 gene was the conspicuous abnormalities in kidney structure, mainly consisting of nephron hypoplasia and tubular atrophy. The renal pathology became more severe with age, resulting in end-stage renal disease $(25,26)$. In the neonatal mouse kidney, the expression of COX-2 increases during the first 4 days after birth and thereafter declines to undetectable levels (31). The initial defects in kidney development in COX-2-null mice are observed at 10 days after birth, with the cortex being abnormally thin with regions of small immature glomeruli and tubular atrophy. In adult COX-2 -/- mice, the nephropathy steps forward tubular dilation, interstitial fibrosis and glomerular sclerosis (32). However, it may possible to overcome this developmental defect by cross-breeding the original COX-2 C57BL/6 deficient mice with a DBA/1 strain (33). The DBA/B6 mice live a full life span with a normal kidney development (34). Recently, Yang et al have studied whether the severity of renal failure in COX-2 deficient mice is also affected by genetic background. Only the male 129/COX-2 deficient mice showed abundant protein casts, dilated tubules and infiltration of inflammatory cells. However, 
the presence of small glomeruli in the nephrogenic zone was observed in all studied strains regardless of genetic background and gender. Therefore, the severity of renal failure in COX-2 null mice is influenced by genetic background whereas the incomplete maturation of outer cortical nephrons appears to be independent of genetic background effects (35).

In addition to its role in postnatal renal development, COX-2 also contributes to modulate specific functions in adult kidney. In the renal cortex, COX-2 expression is localized to the macula densa and the adjacent thick ascending limb, in where COX-2 expression is induced by reductions in the $\mathrm{NaCl}$ concentrations (36). Thanks to COX-2 deficient mice, it has been proposed a role of COX-2 in the stimulation of renin production and secretion following reduced dietary sodium (37) or the inhibition of angiotensin-converting enzyme (38). Under conditions where renin expression and activity are induced in wild-type mice, the kidneys from COX-2 deficient mice do not respond to these stimuli. Therefore, COX-2 appears to be the isoform primarily responsible for maintaining renal homeostatic functions involved in the regulation of salt resorption, fluid volume and blood pressure.

\subsection{Gastrointestinal Tract}

PG synthesis can be demonstrated to occur in every part of the gastrointestinal tract where they have a cytoprotective role. In rat tissues, the PGs levels were greatest in gastric muscle and forestomach, followed by gastric mucosa, colon, rectum, ileum, cecum, duodenum, jejunum and esophagus. The mechanism of the cytoprotective action of PGs is complex and involves the decrease of secretion of gastric acid, the direct vasodilator action on the gastric mucose and the stimulation of viscous mucus (9).

Initially, it has been proposed that PG synthesis dependent on COX-1 is important for maintenance of mucosal integrity. Thus, the inhibition of COX-1 was thought responsible for ulcerative effects of NSAIDs. The reduced gastric toxicity of COX-2 selective inhibition further supported this hypothesis (39). However, the COX-1 deficient mice did not spontaneously develop stomach ulcers (24). Moreover, COX-2 null mice were more susceptible to colonic injury with dextran sodium sulfate than wildtype mice (40). Similarly, SC-560, a selective COX-1 inhibitor, or celecoxib, a selective COX-2 inhibitor, administrated to rats, produced gastric damage. Thus, genetic and pharmacological studies in rodents suggest that the combined inhibition of both COX-1 and COX-2 is required to produce gastric damage

\subsection{Reproduction}

Whereas COX-2 null male mice showed normal fertility, the deletion of the COX-2 gene in female mice resulted in infertility with defects in ovulation, implantation and decidualization. Lim et al (41) observed that few eggs were recovered following superovulation of COX-2 null mice, and only $2 \%$ of the released eggs were fertilized. In preovulatory follicles, COX-2 expression is normally induced by pituitary gonadotropins, indicating that COX-2 accounted for increased ovarian PG production following the luteinizing hormone surge (42). The decrease of PGE2 synthesis in the ovaries of COX-2 knockout mice disrupts cumulus activation, stigmata formation and ovulation, which can be restored by treatment with PGE2 (42). The process of ovulation becomes extremely poor in COX-2 or EP2-null mice, suggesting an important role of COX-2-derived PGE 2 in this process. Moreover, ovulation in younger COX-2 knock out mice that responded to gonadotropins for superovulation, was superior compared to that in adult COX-2 deficient mice, suggesting that ovulatory process becomes more dependent on COX-2- 
derived PGE $\mathrm{P}_{2}$ effects with aging (43). However, follicular growth in vivo and oocyte maturation in vivo or in vitro are, apparently, normal in both knock out models. Furthermore, subsequent in vitro fertilization of oocytes and their development in vitro proceed normally to blastocyst stage. In addition, many of these blastocysts showed signs of zona hatching, suggesting that COX-2-derived $\mathrm{PGE}_{2}$ of maternal origin is not required for oocyte maturation, fertilization or preimplantation development (43).

COX-2 and PGI synthase (PGIS) coexist at the implantation site, suggesting the availability of PGI $_{2}$ directly to uterine cells. Concerning a target receptor for $\mathrm{PGI}_{2}$ in the uterus, PPAR $\delta$ was shown highly colocalized at similar regions of the implantation sites with COX-2 and PGIS; the expression of other known receptors activated by PGI 2 , IP and PPAR $\alpha$, was very low to undetectable. The functionality of PPAR $\delta$ as a $\mathrm{PGI}_{2}$ receptor was further validated in vivo, using COX-2-deficient mice as a model. Administration of cPGI (carbaprostacyclin, PGI 2 agonist) or L-165041 (a selective PPAR $\delta$ agonist) improved implantation and decidualization defects in COX-2(-/-) mice. This effect is further potentiated by RXR agonists (44). Interestingly, coadministration of cPGI with $\mathrm{PGE}_{2}$ markedly improved embryonic and decidual growth in COX-2 deficient mice (44).

In conclusion, the study of COX-2 deficient mice has established the essential role of COX-2 in female reproductive process. The fact that COX-2-derived $\mathrm{PGE}_{2}$ participates in ovulation and fertilization via the EP2 receptor subtype (45), whereas COX-2-derived $\mathrm{PGI}_{2}$ is important for the initial stages of implantation and subsequent decidualization, via the nuclear receptor PPAR $\delta$ in the uterus, illustrate a fascinating distinction as to how specific PGs elicit unique physiological function through utilization of differential signaling pathways.

\subsection{Brain}

Brain (neurons of hippocampus, cerebral cortex, amygdale and hypothalamus) and spinal cord express relatively high basal levels of COX-2, which is though to play a role in fundamental brain functions, such as synaptic activity, synaptic remodeling, memory consolidation and functional hyperemia $(46,47)$. COX-2 expression is rapidly and transiently upregulated in neurons microglia and astrocytes in response to excitatory synaptic transmission mediated by NMDA receptor activation (46) or a variety of neurotoxic stimuli (48-50).

COX-2 deficient mice show increased resistance to focal ischemic injury induced by transient middle cerebral artery occlusion or by NMDA-induced neurotoxicity (51). The lower degree of hippocampal neuronal injury in COX-2 deficient mice agreed with an attenuation of DNA fragmentation in the hippocampus, event reproduced by nimesulide treatment (52). The inhibition of COX-2 protein expression protected the dopaminergic neurons in substantia nigra pars compacta, suggesting a potential therapeutic implication (53). These results show that neuronal COX-2 is likely to function in promoting neuronal injury.

The injury conditions indicated above involve an activation of the NF-kappaB pathway. Rao et al (54) have recently showed that NF-kappaB DNA binding activity was significantly decreased in COX-2 null mice compared to wild-type mice, possibly due to a decrease in brain protein levels of p65, phosphorylated-p65 and phosphorylated-Ikappa-B alpha levels. These results suggest a reciprocal coupling between NF-kappaB and COX-2. 
It has also been developed a C57BL6/J inbred strain transgenic mouse model in which human COX-2 was selectively overexpressed in neurons of the central nervous system using the Thy-1 promoter (HCOX-2 mice). This promoter has a high level of neuron-specific expression that begins in the second postnatal week (55). HCOX-2 mice develop cognitive deficits in an age-dependent manner, associated with a parallel age-dependent increase in neuronal apoptosis and astrocytic activation (22). HCOX-2 mice have been also tested in a model of transient focal ischemia. A significant increase in infarct volume was observed after middle cerebral artery occlusion, supporting previous mentioned studies in COX-2 null mice (56).

\subsection{Cardiovascular System}

COX-1 is highly expressed in the normal vascular tissues, whereas COX-2 expression is elevated in proliferating vascular cells, for example angiogenic microvessels, atherosclerotic lesions and inflamed tissues (57). It has also been reported the expression of COX-2 in ischemic human myocardium and in dilated cardiomyopathy, but not in normal cardiomyocytes (58). All these findings seem indicate a detrimental role of COX-2 in cardiovascular homeostasis.

However, there are also evidences suggesting physiologically important protective actions of COX-2. In contrast of Wong's work, 50\% of COX-2 null mice developed a diffuse myocardial fibrosis, suggesting that COX-2 deficiency might be involved in cardiomyopathy (26). COX-2 protects cardiomyocytes against oxidative stress (59) and the increase in COX-2 activity associated to ischemic preconditioning mediates the protective effects of the late phase of preconditioning against both myocardial stunning and myocardial infarction (60). Furthermore, pharmacological COX-2 inhibition improved cardiac function after myocardial infarction in the mouse (61).

In addition, the clinical experience accumulated with COX-2 inhibitors in the past three years also suggests the protective effects of COX-2 in patients with cardiovascular disease (62). Thus, the Vioxx Gastrointestinal Outcomes Research clinical trial showed a fivefold increase in myocardial infarction in patients treated with rofecoxib compared with the traditional NSAID naproxen (63). The COX-2 inhibitors reduce the production of prostacyclin $\left(\mathrm{PGI}_{2}\right)$ but not that of COX-1-derived thromboxane A2 $\left(\mathrm{TXA}_{2}\right)$. Thus, the effects of $\mathrm{TXA}_{2}$ are exacerbated during extended therapy with specific COX-2 inhibitors (COXIBs), potentially predisposing patients to heart attack and stroke $(64,65)$.

At sight of all these data, we can conclude that the actions of prostanoids in pathological situations are varied and complex. Some appear to be beneficial, countering the worst effects of disease, whereas others contribute to its further development. This complexity might derive from the fact that different cell types in the heart, e.g., myocytes, fibroblasts and endothelial cells produce different prostanoids profiles. The effect of COX-2 induction or inhibition will depend on the cell in which it is expressed, the prostanoids produced, and the ability of surrounding cells to respond to these prostanoids. The outcome of COX-2 activity and subsequent prostanoid signaling will therefore be an exquisite and highly dynamic balance among these different and often conflicting signals. Disturbance of this delicate balance may determine whether prostanoid signals have beneficial or deleterious effects during the development of important cardiovascular pathologies; a comprehensive understanding of prostanoid actions and functions during these disease processes are required. In that sense, in our group we have generated a transgenic mouse that constitutively expresses COX-2 in cardiomyocytes. With this model we try to know with better precision the pathophysiologic role of COX-2 in the heart. 


\subsection{Liver}

There are many studies that reported COX-2 expression and induction in whole liver homogenates, mainly in different experimental models of liver pathology $(66,67)$. The expression and induction of COX-2 in Kupffer cells is well documented. COX-2 expression in these cells was increased by different stimuli such as hyperosmolarity (68), alcohol (66), proinflammatory cytokines and LPS $(69,70)$ both in vitro and in vivo. However, the contribution of hepatocytes to liver PGs synthesis is more controversial. Johston et al (71) using ricin-purified hepatocytes to completely eliminate Kupffer and endothelial cells, demonstrated that hepatocytes do not produce COX products even with conditions favoring lipid peroxidation.

Hepatocytes respond to most of the stimuli that positively regulate COX-2 expression in other cells, including LPS, IL-1 beta and TNF-alpha. Interestingly, fetal hepatocytes, which exhibit a liver phenotype distinct from the adult counterpart, were able to express COX-2 upon challenge with LPS and pro-inflammatory cytokines (72). Regarding the mechanism responsible for the suppression of COX-2 inducibility in adult hepatocytes, our results have shown that the activity of the COX-2 promoter declined rapidly after birth paralleling the expression of C/EBP-alpha in neonatal hepatocytes (73). Attractively, partial hepatectomy $(\mathrm{PH})$ favors hepatocyte de-differentiation and triggers a rapid regenerative response in the remnant tissue to reinstate the organ function and the cell number. In this vein, it has been shown that COX-2 is expressed in liver at 16 hours after PH (74). Studies of PH through animal models have recently been reviewed in greater detail elsewhere (75).

Studies in the physiological significance of COX-2 expression after PH showed alterations in various parameters of cell cycle progression in animals pretreated with NS398, a selective COX-2 inhibitor, and in COX-2 deficient mice (74, 76). In the genetic model of COX-2 targeting in mice, our own data demonstrated that the lack of PG synthesis results in a delay in the first cycle of hepatocyte proliferation. However, measurement of overall liver mass recovery one week after PH failed to show significant differences between control and COX-2 deficient animals, which suggest that other growth-promoting mechanisms play a more significant role in the latter phase of the regeneration process (figure 3).

In conclusion, most of the results indicate that COX-2 expression in hepatocytes is restricted to those situations in which dedifferentiation or proliferation occurs, suggesting an important role of PGs in the onset of liver pathologies including hepatocellular carcinoma (HCC) (77).

\section{COX-2 IN PATHOLOGICAL STATES}

\subsection{Inflammation}

The initial studies for characterizing the COX-2 contribution to the development of inflammation involved the induction of edema by 12-o-tetradecanoylphorbol-13-cetate (TPA), a potent inducer of COX-2 expression, applied topically to the ear of COX-2 knockout mice (78). Surprisingly, the level of edema induced by TPA was not significantly different between wild-type and COX-2 deficient mice.

Sepsis is a systemic inflammatory response to a blood-borne infection that is associated with an extremely high rate of morbidity and mortality. COX-2 deficient mice are resistant to many of the detrimental consequences of endotoxemia such as the leukocyte infiltration into critical organs (kidneys and lung), the induction of nitric oxide synthase 2 and heme oxygenase-1 or activation of NF-kappaB pathway (79). These beneficial effects occur in part by a compensatory increase in IL-10 that 
counterbalances the pro-inflammatory host response to endotoxemia. Thus, COX-2 is a critical component of the lethal response associated with endotoxemia in mice.

Comparing the results observed in endotoxemic COX-2 null mice or mice treated with TPA, it has been deduced that the importance of COX-2 in an inflammatory response may also depend on the initiating stimulus.

\subsection{Tumorigenesis}

The role of COX-2 and the PGs resulting from its enzymatic activity in modulating cell growth and the development of neoplasia is well established mainly in colon cancer (80). Overexpression of COX-2 promotes tumorigenesis in colon cells and in some models of transgenic mice, whereas inhibition of COX-2 by NSAIDs and COXIBs is anti-neoplasic although COX independent pathways could also be involved in the antiproliferative effects of NSAIDs (81, 82). In fact, al least five mechanisms by which COX-2 contributes to tumorigenesis and malignant phenotype have been proposed: inhibition of apoptosis mediated by Bcl-2, Par-4 and protein kinase B (Akt/PKB) signalling (83, 84), increased angiogenesis through the production of VEGF and PGs (85) increased invasiveness via activation of metalloproteinases (86) and conversion of procarcinogens to carcinogens (87).

Is COX-2 overexpression sufficient to induce tumorigenesis? Several COX-2 genetically altered mice models have been developed for answering this question.

\subsubsection{Gastric and Intestinal Tumors}

In 1996 Oshima and collaborators provided definitive evidence that COX-2 is required for intestinal tumorigenesis. In a mouse model of human familial adenomatous polyposis, intestinal tumor development is reduced by the genetic deficiency of COX-2 (88). However, by utilizing COX-1 deficient mice, Lagenbach et al showed that deletion of COX-1 gene also attenuated polyp formation (89). Therefore, both COX-1 and COX-2 may be important in intestinal tumorigenesis.

Accumulating evidence shows that COX-2 expression is also induced in the gastric cancer tissues (90). Among various prostanoids, $\mathrm{PGE}_{2}$ appears to be the responsible for cancer development (91). To investigate the role of COX-2 in gastric tumorigenesis, transgenic mice simultaneously expressing COX-2 and microsomal $\mathrm{PGE}_{2}$ synthase was generated. The specific gastric epithelial cell expression was obtained by using the cytokeratin 19 (K19) promoter (92). The transgenic mice developed metaplasia, hyperplasia and tumors in the glandular stomach with heavy macrophage infiltrations (20).

\subsubsection{Breast Cancer}

The question of whether COX-2 overepression is sufficient to induce tumorigenesis was addressed by human COX-2 overexpression in the mammary glands of CD1 mice using the mouse mammary tumor virus promoter (MMTV). This promoter is highly expressed in the mammary epithelium during pregnancy and lactation (93). Female virgin COX-2 transgenic mice showed precocious alveolar differentiation and enhanced expression of beta casein gene. Multiparous females exhibited exaggerated incidence of focal mammary gland hyperplasia, dysplasia, and transformation into metastatic tumors. The reduced levels of Bax and Bcl-XL proteins and the decrease of Bcl-2 levels in COX-2 induced tumors suggested that decreased apoptosis of mammary epithelial cells contribute to tumorigenesis (21). Moreover, $\mathrm{PGE}_{2}$ stimulated the expression of angiogenic regulatory genes in mammary tumor cells isolated from MMTV-COX-2 transgenic mice (94). These results define, in part, the molecular 
basis of how COX-2 transforms the mammary gland into a tumorigenic state. Recently, it has been showed that PGE 2 stimulates angiogenesis via the $\mathrm{EP}_{2}$ receptor, mediating VEGF upregulation via the cAMP/PKA pathway (95).

Narko and collaborators have been characterized the MMTV-COX-2 FVB/N transgenic mice (96). FVB/N is an inbred strain which has robust reproductive characteristics and is susceptible to breast cancer formation. MMTV-COX-2 FVB/N transgenic mice had high incidence of mammary tumors similar to CD1 mice suggesting that observed phenotype is due to COX2 expression and not an aberrant effect of site of integration.

\subsubsection{Skin Carcinogenesis}

Recent transgenic overexpression studies in which COX-2 was targeted to the skin of transgenic mice support the notion that upregulated expression of COX-2, perhaps induced by carcinogenic stimuli or other tumor promoters, is an important contributor of tumorigenesis. In mice and humans, deregulated expression of COX-2, but not of COX-1, is characteristic of epithelial tumors, including squamous cell carcinomas of skin (97). To explore the function of COX-2 in epidermis, a keratin 5 promoter was used to direct COX-2 expression to basal epidermal cells and the pilosebaceous unit of mouse skin (K5-COX-2) (23). The transgenic animals did not exhibit symptoms of inflammation, indicating that COX-2 expression alone is not sufficient to initiate an inflammatory response in mouse skin.

K5-COX-2 mice morphogenesis of pelage and the number of hair follicles was reduced probably due to an impairment of hair follicle induction. Furthermore, transgenic mice developed alopecia (98). Aberrant COX-2 expression in basal gland epithelial cells correlated with sebaceous gland hyperplasia and increase of epicutaneous sebum levels (23). The K5-COX-2 transgenic mice did not develop skin tumors spontaneously but did so after a single application of an initiating dose of the carcinogen 7, 12-dimethyl-benz[a]anthracene (DMBA) (99). Thus, overexpression of COX-2 targeted to basal keratinocytes contributes to skin-tumor promotion and progression by establishing a preneoplasic skin phenotype. Nevertheless, these results are in controversy with other authors who have shown that the COX-2 deficiency altered epidermal differentiation and reduced mouse skin tumorigenesis (100).

COX-2 null mice have been also used to evaluate the involvement of COX-2 activity in sulfur mustard induced skin toxicity (101). Sulfur mustard (SM) is a potent vesicant and chemical warfare agent that induces tissue damage involving an inflammatory response (102). The relatively low susceptibility of COX-2 null mice to SM, expressed by reduced ear swelling and absence of epidermal ulceration and encrustation, demonstrates that COX-2 actively participates in the acute phase of inflammation caused by SM.

\subsubsection{Hepatocellular Carcinoma}

Although the pathogenesis of hepatocellular carcinoma (HCC) remains poorly defined, several studies indicate that this is a multifactorial, multistep process involving the alteration of oncogenes, tumor suppressor genes and host chromosomes, as well as an abnormal expression of growth factors and COX-2 on the whole resulting in a reduced apoptosis.

COX-2 expression in human hepatoma cell lines is well documented. COX-2 is expressed in 75\% of different hepatoma cell lines studied, for example, HepG2, HuH7, Hep3B, Sk-hep 1 and SMMC-7721 cells (103-107). Failure of apoptosis is an important event in tumor progression and resistance to cytotoxic therapy (108). Treatment of these cells with COX-2 inhibitors, 
such as aspirin, nimesulide, NS-398 or celecoxib, inhibited cell growth, invasiveness and proliferation at the time that induced apoptosis. With respect to the mechanisms involved, it has been proposed that COX-2 promotes hepatocellular carcinoma progression through Akt activation (109). Aspirin and NS-398 inhibit HGF-induced invasiveness in HepG2 cells through ERK1/2 activation (106) and apoptosis induced by COX-2 inhibitors was correlated with the activation of caspase-9, 3 and 6 (103).

However, the in vitro anti-HCC effect of NSAIDs and COXIBs needs to be confirmed in animal models in vivo. In this sense, we have developed, as an initial approach, an in vivo model to deliver the human COX-2 gene to the mouse liver via hydrodynamicsbased transient transfection as described previously (110). Through this model, it has been demonstrated that PGs produced by COX-2 expression protected the liver against Fas-mediated apoptosis. The mechanism involves potent inhibition of caspases 3 and 9 (unpublished data). Moreover, our group is working to develop a transgenic mice model that constitutively express COX-2 in hepatocytes to confirm the involvement of COX-2 in HCC and the anti-tumoral effects of the COX-2 inhibitors.

\section{SUMMARY AND PERSPECTIVES}

Generation and characterization of COX-2 genetically altered mouse models, as reviewed in this article, have greatly facilitated identification of the mechanisms by which the COX-2 contributed to normal physiology and various pathological states (table 1). However, caution should be exercised when we used this powerful technology because, for example, differences in genetic background of different mouse strains can affect transgene expression and phenotype due to strain specific modifiers of expression.

Nevertheless, future refinement and generation of new COX-transgenic models, including the generation of conditional gene-targeted mouse models that may allow for the temporal and spatial control of gene expression, would be a tremendous advantage in exploring the genetic basis of COX-2 function and dysfunction. Furthermore, it can be anticipated that new approaches will appear which permit control not only the COX-2 activity, spatially and temporally, but also quantitatively, which is known to be central to many biological process.

\section{ACKNOWLEDGEMENTS}

This work was supported by grants from Instituto de Salud Carlos III (Red de Centros C03/01), Generalitat Valenciana (GRUPOS03/072), Ministerio de Educación y Ciencia (SAF2004-00957) and Comunidad de Madrid (CAM2004GR/SAL/0388).

\section{REFERENCES}

1. Smith, W. L., D. L. DeWitt \& R. M. Garavito: Cyclooxygenases: structural, cellular, and molecular biology. Annu Rev Biochem, 69, 145-82(2000)

2. Negishi, M., Y. Sugimoto \& A. Ichikawa: Molecular mechanisms of diverse actions of prostanoid receptors. Biochim Biophys Acta, 1259, 109-19(1995)

3. Forman, B. M., J. Chen \& R. M. Evans: The peroxisome proliferator-activated receptors: ligands and activators. Ann $N$ $Y$ Acad Sci, 804, 266-75(1996)

4. Tanabe, T. \& N. Tohnai: Cyclooxygenase isozymes and their gene structures and expression. Prostaglandins Other Lipid Mediat, 68-69, 95-114(2002)

5. Smith, W. L. \& R. Langenbach: Why there are two cyclooxygenase isozymes. J Clin Invest, 107, 1491-5(2001)

6. Shitashige, M., I. Morita \& S. Murota: Different substrate utilization between prostaglandin endoperoxide H synthase-1 and -2 in NIH3T3 fibroblasts. Biochim Biophys Acta, 1389, 57-66(1998)

7. Reddy, S. T. \& H. R. Herschman: Prostaglandin synthase-1 and prostaglandin synthase-2 are coupled to distinct phospholipases for the generation of prostaglandin D2 in activated mast cells. J Biol Chem, 272, 3231-7(1997) 
8. Murakami, M., T. Kambe, S. Shimbara, K. Higashino, K. Hanasaki, H. Arita, M. Horiguchi, M. Arita, H. Arai, K. Inoue \& I. Kudo: Different functional aspects of the group II subfamily (Types IIA and V) and type X secretory phospholipase $\mathrm{A}(2) \mathrm{s}$ in regulating arachidonic acid release and prostaglandin generation. Implications of cyclooxygenase-2 induction and phospholipid scramblase-mediated cellular membrane perturbation. J Biol Chem, 274, 31435-44(1999)

9. Simmons, D. L., R. M. Botting \& T. Hla: Cyclooxygenase isozymes: the biology of prostaglandin synthesis and inhibition. Pharmacol Rev, 56, 387-437(2004)

10. Okahara, K., B. Sun \& J. Kambayashi: Upregulation of prostacyclin synthesis-related gene expression by shear stress in vascular endothelial cells. Arterioscler Thromb Vasc Biol, 18, 1922-6(1998)

11. Bryant, C. E., I. Appleton \& J. A. Mitchell: Vascular endothelial growth factor upregulates constitutive cyclooxygenase 1 in primary bovine and human endothelial cells. Life Sci, 62, 2195-201(1998)

12. Duque, J., M. Fresno \& M. A. Iniguez: Expression and function of the nuclear factor of activated T cells in colon carcinoma cells: involvement in the regulation of cyclooxygenase-2. J Biol Chem, 280, 8686-93(2005)

13. Hernandez, G. L., O. V. Volpert, M. A. Iniguez, E. Lorenzo, S. Martinez-Martinez, R. Grau, M. Fresno \& J. M. Redondo: Selective inhibition of vascular endothelial growth factor-mediated angiogenesis by cyclosporin A: roles of the nuclear factor of activated T cells and cyclooxygenase 2. J Exp Med, 193, 607-20(2001)

14. Sugimoto, T., M. Haneda, H. Sawano, K. Isshiki, S. Maeda, D. Koya, K. Inoki, H. Yasuda, A. Kashiwagi \& R. Kikkawa: Endothelin-1 induces cyclooxygenase-2 expression via nuclear factor of activated T-cell transcription factor in glomerular mesangial cells. J Am Soc Nephrol, 12, 1359-68(2001)

15. Vane, J. R.: Inhibition of prostaglandin synthesis as a mechanism of action for aspirin-like drugs. Nat New Biol, 231, 232-5(1971)

16. Hanif, R., A. Pittas, Y. Feng, M. I. Koutsos, L. Qiao, L. Staiano-Coico, S. I. Shiff \& B. Rigas: Effects of nonsteroidal anti-inflammatory drugs on proliferation and on induction of apoptosis in colon cancer cells by a prostaglandinindependent pathway. Biochem Pharmacol, 52, 237-45(1996)

17. Piazza, G. A., A. K. Rahm, T. S. Finn, B. H. Fryer, H. Li, A. L. Stoumen, R. Pamukcu \& D. J. Ahnen: Apoptosis primarily accounts for the growth-inhibitory properties of sulindac metabolites and involves a mechanism that is independent of cyclooxygenase inhibition, cell cycle arrest, and p53 induction. Cancer Res, 57, 2452-9(1997)

18. Elder, D. J., D. E. Halton, A. Hague \& C. Paraskeva: Induction of apoptotic cell death in human colorectal carcinoma cell lines by a cyclooxygenase-2 (COX-2)-selective nonsteroidal anti-inflammatory drug: independence from COX-2 protein expression. Clin Cancer Res, 3, 1679-83(1997)

19. Nagy, A., M. Gertsenstein, K. Vintersten \& R. Behringer: Manipulating the Mouse Embryo: a laboratory manual. Cold Spring Harbor Laboratory Press, (2003)

20. Oshima, H., M. Oshima, K. Inaba \& M. M. Taketo: Hyperplastic gastric tumors induced by activated macrophages in COX-2/mPGES-1 transgenic mice. Embo J, 23, 1669-78(2004)

21. Liu, C. H., S. H. Chang, K. Narko, O. C. Trifan, M. T. Wu, E. Smith, C. Haudenschild, T. F. Lane \& T. Hla: Overexpression of cyclooxygenase-2 is sufficient to induce tumorigenesis in transgenic mice. J Biol Chem, 276, 18563$9(2001)$

22. Andreasson, K. I., A. Savonenko, S. Vidensky, J. J. Goellner, Y. Zhang, A. Shaffer, W. E. Kaufmann, P. F. Worley, P. Isakson \& A. L. Markowska: Age-dependent cognitive deficits and neuronal apoptosis in cyclooxygenase-2 transgenic mice. J Neurosci, 21, 8198-209(2001)

23. Neufang, G., G. Furstenberger, M. Heidt, F. Marks \& K. Muller-Decker: Abnormal differentiation of epidermis in transgenic mice constitutively expressing cyclooxygenase-2 in skin. Proc Natl Acad Sci U S A, 98, 7629-34(2001)

24. Langenbach, R., S. G. Morham, H. F. Tiano, C. D. Loftin, B. I. Ghanayem, P. C. Chulada, J. F. Mahler, C. A. Lee, E. H. Goulding, K. D. Kluckman, H. S. Kim \& O. Smithies: Prostaglandin synthase 1 gene disruption in mice reduces arachidonic acid-induced inflammation and indomethacin-induced gastric ulceration. Cell, 83, 483-92(1995)

25. Morham, S. G., R. Langenbach, C. D. Loftin, H. F. Tiano, N. Vouloumanos, J. C. Jennette, J. F. Mahler, K. D. Kluckman, A. Ledford, C. A. Lee \& O. Smithies: Prostaglandin synthase 2 gene disruption causes severe renal pathology in the mouse. Cell, 83, 473-82(1995)

26. Dinchuk, J. E., B. D. Car, R. J. Focht, J. J. Johnston, B. D. Jaffee, M. B. Covington, N. R. Contel, V. M. Eng, R. J. Collins, P. M. Czerniak \& et al.: Renal abnormalities and an altered inflammatory response in mice lacking cyclooxygenase II. Nature, 378, 406-9(1995)

27. Loftin, C. D., D. B. Trivedi, H. F. Tiano, J. A. Clark, C. A. Lee, J. A. Epstein, S. G. Morham, M. D. Breyer, M. Nguyen, B. M. Hawkins, J. L. Goulet, O. Smithies, B. H. Koller \& R. Langenbach: Failure of ductus arteriosus closure and remodeling in neonatal mice deficient in cyclooxygenase-1 and cyclooxygenase-2. Proc Natl Acad Sci U S A, 98, 1059-64(2001)

28. Kitahara, M., F. Eitner, T. Ostendorf, U. Kunter, U. Janssen, R. Westenfeld, K. Matsui, D. Kerjaschki \& J. Floege: Selective cyclooxygenase-2 inhibition impairs glomerular capillary healing in experimental glomerulonephritis. $J \mathrm{Am}$ Soc Nephrol, 13, 1261-70(2002)

29. Tomasoni, S., M. Noris, S. Zappella, E. Gotti, F. Casiraghi, S. Bonazzola, A. Benigni \& G. Remuzzi: Upregulation of renal and systemic cyclooxygenase-2 in patients with active lupus nephritis. J Am Soc Nephrol, 9, 1202-12(1998)

30. Komers, R., S. Anderson \& M. Epstein: Renal and cardiovascular effects of selective cyclooxygenase-2 inhibitors. Am J Kidney Dis, 38, 1145-57(2001)

31. Komhoff, M., J. L. Wang, H. F. Cheng, R. Langenbach, J. A. McKanna, R. C. Harris \& M. D. Breyer: Cyclooxygenase-2-selective inhibitors impair glomerulogenesis and renal cortical development. Kidney Int, 57, 41422(2000)

32. Norwood, V. F., S. G. Morham \& O. Smithies: Postnatal development and progression of renal dysplasia in cyclooxygenase-2 null mice. Kidney Int, 58, 2291-300(2000) 
33. Ballou, L. R., R. M. Botting, S. Goorha, J. Zhang \& J. R. Vane: Nociception in cyclooxygenase isozyme-deficient mice. Proc Natl Acad Sci U S A, 97, 10272-6(2000)

34. Laulederkind, S. J., B. M. Wall, L. R. Ballou \& R. Raghow: Renal pathology resulting from PGHS-2 gene ablation in DBA/B6 mice. Prostaglandins Other Lipid Mediat, 70, 161-8(2002)

35. Yang, T., Y. G. Huang, W. Ye, P. Hansen, J. B. Schnermann \& J. P. Briggs: Influence of genetic background and gender on hypertension and renal failure in COX-2-deficient mice. Am J Physiol Renal Physiol, 288, F1125-32(2005)

36. Harris, R. C., J. A. McKanna, Y. Akai, H. R. Jacobson, R. N. Dubois \& M. D. Breyer: Cyclooxygenase-2 is associated with the macula densa of rat kidney and increases with salt restriction. $J$ Clin Invest, 94, 2504-10(1994)

37. Yang, T., Y. Endo, Y. G. Huang, A. Smart, J. P. Briggs \& J. Schnermann: Renin expression in COX-2-knockout mice on normal or low-salt diets. Am J Physiol Renal Physiol, 279, F819-25(2000)

38. Cheng, H. F., J. L. Wang, M. Z. Zhang, S. W. Wang, J. A. McKanna \& R. C. Harris: Genetic deletion of COX-2 prevents increased renin expression in response to ACE inhibition. Am J Physiol Renal Physiol, 280, F449-56(2001)

39. Wallace, J. L. \& A. W. Tigley: Review article: new insights into prostaglandins and mucosal defence. Aliment Pharmacol Ther, 9, 227-35(1995)

40. Morteau, O., S. G. Morham, R. Sellon, L. A. Dieleman, R. Langenbach, O. Smithies \& R. B. Sartor: Impaired mucosal defense to acute colonic injury in mice lacking cyclooxygenase-1 or cyclooxygenase-2. J Clin Invest, 105, 469$78(2000)$

41. Lim, H., B. C. Paria, S. K. Das, J. E. Dinchuk, R. Langenbach, J. M. Trzaskos \& S. K. Dey: Multiple female reproductive failures in cyclooxygenase 2-deficient mice. Cell, 91, 197-208(1997)

42. Davis, B. J., D. E. Lennard, C. A. Lee, H. F. Tiano, S. G. Morham, W. C. Wetsel \& R. Langenbach: Anovulation in cyclooxygenase-2-deficient mice is restored by prostaglandin E2 and interleukin-1beta. Endocrinology, 140, 268595(1999)

43. Matsumoto, H., W. Ma, W. Smalley, J. Trzaskos, R. M. Breyer \& S. K. Dey: Diversification of cyclooxygenase-2derived prostaglandins in ovulation and implantation. Biol Reprod, 64, 1557-65(2001)

44. Lim, H., R. A. Gupta, W. G. Ma, B. C. Paria, D. E. Moller, J. D. Morrow, R. N. DuBois, J. M. Trzaskos \& S. K. Dey: Cyclo-oxygenase-2-derived prostacyclin mediates embryo implantation in the mouse via PPARdelta. Genes Dev, 13, 1561-74(1999)

45. Kennedy, C. R., Y. Zhang, S. Brandon, Y. Guan, K. Coffee, C. D. Funk, M. A. Magnuson, J. A. Oates, M. D. Breyer \& R. M. Breyer: Salt-sensitive hypertension and reduced fertility in mice lacking the prostaglandin EP2 receptor. Nat Med, 5, 217-20(1999)

46. Yamagata, K., K. I. Andreasson, W. E. Kaufmann, C. A. Barnes \& P. F. Worley: Expression of a mitogen-inducible cyclooxygenase in brain neurons: regulation by synaptic activity and glucocorticoids. Neuron, 11, 371-86(1993)

47. Minghetti, L.: Cyclooxygenase-2 (COX-2) in inflammatory and degenerative brain diseases. J Neuropathol Exp Neurol, 63, 901-10(2004)

48. Nogawa, S., F. Zhang, M. E. Ross \& C. Iadecola: Cyclo-oxygenase-2 gene expression in neurons contributes to ischemic brain damage. $J$ Neurosci, 17, 2746-55(1997)

49. Nakayama, M., K. Uchimura, R. L. Zhu, T. Nagayama, M. E. Rose, R. A. Stetler, P. C. Isakson, J. Chen \& S. H. Graham: Cyclooxygenase-2 inhibition prevents delayed death of CA1 hippocampal neurons following global ischemia. Proc Natl Acad Sci U S A, 95, 10954-9(1998)

50. Tomimoto, H., I. Akiguchi, H. Wakita, J. X. Lin \& H. Budka: Cyclooxygenase-2 is induced in microglia during chronic cerebral ischemia in humans. Acta Neuropathol (Berl), 99, 26-30(2000)

51. Iadecola, C., K. Niwa, S. Nogawa, X. Zhao, M. Nagayama, E. Araki, S. Morham \& M. E. Ross: Reduced susceptibility to ischemic brain injury and N-methyl-D-aspartate-mediated neurotoxicity in cyclooxygenase-2-deficient mice. Proc Natl Acad Sci U S A, 98, 1294-9(2001)

52. Sasaki, T., K. Kitagawa, K. Yamagata, T. Takemiya, S. Tanaka, E. Omura-Matsuoka, S. Sugiura, M. Matsumoto \& M. Hori: Amelioration of hippocampal neuronal damage after transient forebrain ischemia in cyclooxygenase-2-deficient mice. J Cereb Blood Flow Metab, 24, 107-13(2004)

53. Feng, Z., D. Li, P. C. Fung, Z. Pei, D. B. Ramsden \& S. L. Ho: COX-2-deficient mice are less prone to MPTPneurotoxicity than wild-type mice. Neuroreport, 14, 1927-9(2003)

54. Rao, J. S., R. Langenbach \& F. Bosetti: Down-regulation of brain nuclear factor-kappa B pathway in the cyclooxygenase-2 knockout mouse. Brain Res Mol Brain Res, 139, 217-24(2005)

55. Vidal, M., R. Morris, F. Grosveld \& E. Spanopoulou: Tissue-specific control elements of the Thy-1 gene. Embo J, 9 , 833-40(1990)

56. Dore, S., T. Otsuka, T. Mito, N. Sugo, T. Hand, L. Wu, P. D. Hurn, R. J. Traystman \& K. Andreasson: Neuronal overexpression of cyclooxygenase-2 increases cerebral infarction. Ann Neurol, 54, 155-62(2003)

57. Schonbeck, U., G. K. Sukhova, P. Graber, S. Coulter \& P. Libby: Augmented expression of cyclooxygenase-2 in human atherosclerotic lesions. Am J Pathol, 155, 1281-91(1999)

58. Wong, S. C., M. Fukuchi, P. Melnyk, I. Rodger \& A. Giaid: Induction of cyclooxygenase-2 and activation of nuclear factor-kappaB in myocardium of patients with congestive heart failure. Circulation, 98, 100-3(1998)

59. Adderley, S. R. \& D. J. Fitzgerald: Oxidative damage of cardiomyocytes is limited by extracellular regulated kinases 1/2-mediated induction of cyclooxygenase-2. J Biol Chem, 274, 5038-46(1999)

60. Bolli, R., K. Shinmura, X. L. Tang, E. Kodani, Y. T. Xuan, Y. Guo \& B. Dawn: Discovery of a new function of cyclooxygenase (COX)-2: COX-2 is a cardioprotective protein that alleviates ischemia/reperfusion injury and mediates the late phase of preconditioning. Cardiovasc Res, 55, 506-19(2002)

61. LaPointe, M. C., M. Mendez, A. Leung, Z. Tao \& X. P. Yang: Inhibition of cyclooxygenase-2 improves cardiac function after myocardial infarction in the mouse. Am J Physiol Heart Circ Physiol, 286, H1416-24(2004) 
62. Mukherjee, D., S. E. Nissen \& E. J. Topol: Risk of cardiovascular events associated with selective COX-2 inhibitors. Jama, 286, 954-9(2001)

63. Bombardier, C., L. Laine, A. Reicin, D. Shapiro, R. Burgos-Vargas, B. Davis, R. Day, M. B. Ferraz, C. J. Hawkey, M. C. Hochberg, T. K. Kvien \& T. J. Schnitzer: Comparison of upper gastrointestinal toxicity of rofecoxib and naproxen in patients with rheumatoid arthritis. VIGOR Study Group. $N$ Engl J Med, 343, 1520-8, 2 p following 1528(2000)

64. FitzGerald, G. A.: COX-2 and beyond: Approaches to prostaglandin inhibition in human disease. Nat Rev Drug Discov, 2, 879-90(2003)

65. Justice, E. \& D. M. Carruthers: Cardiovascular risk and COX-2 inhibition in rheumatological practice. J Hum Hypertens, 19, 1-5(2005)

66. Nanji, A. A., L. Miao, P. Thomas, A. Rahemtulla, S. Khwaja, S. Zhao, D. Peters, S. R. Tahan \& A. J. Dannenberg: Enhanced cyclooxygenase-2 gene expression in alcoholic liver disease in the rat. Gastroenterology, 112, 943-51(1997)

67. Yamamoto, H., M. Kondo, S. Nakamori, H. Nagano, K. Wakasa, Y. Sugita, J. Chang-De, S. Kobayashi, B. Damdinsuren, K. Dono, K. Umeshita, M. Sekimoto, M. Sakon, N. Matsuura \& M. Monden: JTE-522, a cyclooxygenase-2 inhibitor, is an effective chemopreventive agent against rat experimental liver fibrosis1. Gastroenterology, 125, 556-71(2003)

68. Zhang, F., U. Warskulat, M. Wettstein, R. Schreiber, H. P. Henninger, K. Decker \& D. Haussinger: Hyperosmolarity stimulates prostaglandin synthesis and cyclooxygenase-2 expression in activated rat liver macrophages. Biochem J, 312 ( Pt 1), 135-43(1995)

69. Kiemer, A. K., T. Hartung, C. Huber \& A. M. Vollmar: Phyllanthus amarus has anti-inflammatory potential by inhibition of iNOS, COX-2, and cytokines via the NF-kappaB pathway. J Hepatol, 38, 289-97(2003)

70. Shimohashi, N., M. Nakamuta, K. Uchimura, R. Sugimoto, H. Iwamoto, M. Enjoji \& H. Nawata: Selenoorganic compound, ebselen, inhibits nitric oxide and tumor necrosis factor-alpha production by the modulation of jun-Nterminal kinase and the NF-kappab signaling pathway in rat Kupffer cells. J Cell Biochem, 78, 595-606(2000)

71. Johnston, D. E. \& C. Kroening: Stimulation of prostaglandin synthesis in cultured liver cells by CCl4. Hepatology, 24, 677-84(1996)

72. Martin-Sanz, P., N. A. Callejas, M. Casado, M. J. Diaz-Guerra \& L. Bosca: Expression of cyclooxygenase-2 in foetal rat hepatocytes stimulated with lipopolysaccharide and pro-inflammatory cytokines. Br J Pharmacol, 125, 13139(1998)

73. Callejas, N. A., L. Bosca, C. S. Williams, B. R. Du \& P. Martin-Sanz: Regulation of cyclooxygenase 2 expression in hepatocytes by CCAAT/enhancer-binding proteins. Gastroenterology, 119, 493-501(2000)

74. Casado, M., N. A. Callejas, J. Rodrigo, X. Zhao, S. K. Dey, L. Bosca \& P. Martin-Sanz: Contribution of cyclooxygenase 2 to liver regeneration after partial hepatectomy. Faseb J, 15, 2016-8(2001)

75. Hortelano, S., M. Zeini, M. Casado, P. Martin Sanz \& L. Boscá: Animal models for the study of liver regeneration. Role of nitric oxide and prostaglandins. Frontiers in Bioscience, in press, (2006)

76. Fernandez-Martinez, A., N. A. Callejas, M. Casado, L. Bosca \& P. Martin-Sanz: Thioacetamide-induced liver regeneration involves the expression of cyclooxygenase 2 and nitric oxide synthase 2 in hepatocytes. $J$ Hepatol, 40, 963-70(2004)

77. Kondo, M., H. Yamamoto, H. Nagano, J. Okami, Y. Ito, J. Shimizu, H. Eguchi, A. Miyamoto, K. Dono, K. Umeshita, N. Matsuura, K. Wakasa, S. Nakamori, M. Sakon \& M. Monden: Increased expression of COX-2 in nontumor liver tissue is associated with shorter disease-free survival in patients with hepatocellular carcinoma. Clin Cancer Res, 5, 4005-12(1999)

78. Kujubu, D. A., B. S. Fletcher, B. C. Varnum, R. W. Lim \& H. R. Herschman: TIS10, a phorbol ester tumor promoterinducible mRNA from Swiss 3T3 cells, encodes a novel prostaglandin synthase/cyclooxygenase homologue. J Biol Chem, 266, 12866-72(1991)

79. Ejima, K., M. D. Layne, I. M. Carvajal, P. A. Kritek, R. M. Baron, Y. H. Chen, J. Vom Saal, B. D. Levy, S. F. Yet \& M. A. Perrella: Cyclooxygenase-2-deficient mice are resistant to endotoxin-induced inflammation and death. Faseb J, 17, 1325-7(2003)

80. Gupta, R. A. \& R. N. Dubois: Colorectal cancer prevention and treatment by inhibition of cyclooxygenase-2. Nat Rev Cancer, 1, 11-21(2001)

81. Tegeder, I., J. Pfeilschifter \& G. Geisslinger: Cyclooxygenase-independent actions of cyclooxygenase inhibitors. Faseb $J, 15,2057-72(2001)$

82. DeWitt, D. L.: Cox-2-selective inhibitors: the new super aspirins. Mol Pharmacol, 55, 625-31(1999)

83. Sheng, H., J. Shao \& R. N. Dubois: K-Ras-mediated increase in cyclooxygenase 2 mRNA stability involves activation of the protein kinase B1. Cancer Res, 61, 2670-5(2001)

84. Zhang, Z. \& R. N. DuBois: Par-4, a proapoptotic gene, is regulated by NSAIDs in human colon carcinoma cells. Gastroenterology, 118, 1012-7(2000)

85. Sonoshita, M., K. Takaku, N. Sasaki, Y. Sugimoto, F. Ushikubi, S. Narumiya, M. Oshima \& M. M. Taketo: Acceleration of intestinal polyposis through prostaglandin receptor EP2 in Apc(Delta 716) knockout mice. Nat Med, 7, 1048-51(2001)

86. Callejas, N. A., M. Casado, M. J. Diaz-Guerra, L. Bosca \& P. Martin-Sanz: Expression of cyclooxygenase-2 promotes the release of matrix metalloproteinase-2 and -9 in fetal rat hepatocytes. Hepatology, 33, 860-7(2001)

87. Vogel, C.: Prostaglandin H synthases and their importance in chemical toxicity. Curr Drug Metab, 1, 391-404(2000)

88. Oshima, M., J. E. Dinchuk, S. L. Kargman, H. Oshima, B. Hancock, E. Kwong, J. M. Trzaskos, J. F. Evans \& M. M. Taketo: Suppression of intestinal polyposis in Apc delta716 knockout mice by inhibition of cyclooxygenase 2 (COX2). Cell, 87, 803-9(1996) 
89. Chulada, P. C., M. B. Thompson, J. F. Mahler, C. M. Doyle, B. W. Gaul, C. Lee, H. F. Tiano, S. G. Morham, O. Smithies \& R. Langenbach: Genetic disruption of Ptgs-1, as well as Ptgs-2, reduces intestinal tumorigenesis in Min mice. Cancer Res, 60, 4705-8(2000)

90. Ristimaki, A., N. Honkanen, H. Jankala, P. Sipponen \& M. Harkonen: Expression of cyclooxygenase-2 in human gastric carcinoma. Cancer Res, 57, 1276-80(1997)

91. Yoshimatsu, K., D. Golijanin, P. B. Paty, R. A. Soslow, P. J. Jakobsson, R. A. DeLellis, K. Subbaramaiah \& A. J. Dannenberg: Inducible microsomal prostaglandin E synthase is overexpressed in colorectal adenomas and cancer. Clin Cancer Res, 7, 3971-6(2001)

92. Brembeck, F. H., J. Moffett, T. C. Wang \& A. K. Rustgi: The keratin 19 promoter is potent for cell-specific targeting of genes in transgenic mice. Gastroenterology, 120, 1720-8(2001)

93. Lane, T. F. \& P. Leder: Wnt-10b directs hypermorphic development and transformation in mammary glands of male and female mice. Oncogene, 15, 2133-44(1997)

94. Chang, S. H., C. H. Liu, R. Conway, D. K. Han, K. Nithipatikom, O. C. Trifan, T. F. Lane \& T. Hla: Role of prostaglandin E2-dependent angiogenic switch in cyclooxygenase 2-induced breast cancer progression. Proc Natl Acad Sci U S A, 101, 591-6(2004)

95. Chang, S. H., C. H. Liu, M. T. Wu \& T. Hla: Regulation of vascular endothelial cell growth factor expression in mouse mammary tumor cells by the EP2 subtype of the prostaglandin E2 receptor. Prostaglandins Other Lipid Mediat, 76, 4858(2005)

96. Narko, K., B. Zweifel, O. Trifan, A. Ristimaki, T. F. Lane \& T. Hla: COX-2 inhibitors and genetic background reduce mammary tumorigenesis in cyclooxygenase-2 transgenic mice. Prostaglandins Other Lipid Mediat, 76, 86-94(2005)

97. Muller-Decker, K., G. Reinerth, P. Krieg, R. Zimmermann, H. Heise, C. Bayerl, F. Marks \& G. Furstenberger: Prostaglandin-H-synthase isozyme expression in normal and neoplastic human skin. Int J Cancer, 82, 648-56(1999)

98. Muller-Decker, K., C. Leder, M. Neumann, G. Neufang, C. Bayerl, J. Schweizer, F. Marks \& G. Furstenberger: Expression of cyclooxygenase isozymes during morphogenesis and cycling of pelage hair follicles in mouse skin: precocious onset of the first catagen phase and alopecia upon cyclooxygenase-2 overexpression. J Invest Dermatol, $121,661-8(2003)$

99. Muller-Decker, K., G. Neufang, I. Berger, M. Neumann, F. Marks \& G. Furstenberger: Transgenic cyclooxygenase-2 overexpression sensitizes mouse skin for carcinogenesis. Proc Natl Acad Sci U S A, 99, 12483-8(2002)

100. Tiano, H. F., C. D. Loftin, J. Akunda, C. A. Lee, J. Spalding, A. Sessoms, D. B. Dunson, E. G. Rogan, S. G. Morham, R. C. Smart \& R. Langenbach: Deficiency of either cyclooxygenase (COX)-1 or COX-2 alters epidermal differentiation and reduces mouse skin tumorigenesis. Cancer Res, 62, 3395-401(2002)

101. Wormser, U., R. Langenbach, S. Peddada, A. Sintov, B. Brodsky \& A. Nyska: Reduced sulfur mustard-induced skin toxicity in cyclooxygenase-2 knockout and celecoxib-treated mice. Toxicol Appl Pharmacol, 200, 40-7(2004)

102. Wormser, U.: Toxicology of mustard gas. Trends Pharmacol Sci, 12, 164-7(1991)

103. Kern, M. A., D. Schubert, D. Sahi, M. M. Schoneweiss, I. Moll, A. M. Haugg, H. P. Dienes, K. Breuhahn \& P. Schirmacher: Proapoptotic and antiproliferative potential of selective cyclooxygenase-2 inhibitors in human liver tumor cells. Hepatology, 36, 885-94(2002)

104. Hu, K. Q., C. H. Yu, Y. Mineyama, J. D. McCracken, D. J. Hillebrand \& M. Hasan: Inhibited proliferation of cyclooxygenase-2 expressing human hepatoma cells by NS-398, a selective COX-2 inhibitor. Int J Oncol, 22, 75763(2003)

105. Cheng, J., H. Imanishi, Y. Amuro \& T. Hada: NS-398, a selective cyclooxygenase 2 inhibitor, inhibited cell growth and induced cell cycle arrest in human hepatocellular carcinoma cell lines. Int J Cancer, 99, 755-61(2002)

106. Abiru, S., K. Nakao, T. Ichikawa, K. Migita, M. Shigeno, M. Sakamoto, H. Ishikawa, K. Hamasaki, K. Nakata \& K. Eguchi: Aspirin and NS-398 inhibit hepatocyte growth factor-induced invasiveness of human hepatoma cells. Hepatology, 35, 1117-24(2002)

107. Tian, G., J. P. Yu, H. S. Luo, B. P. Yu, H. Yue, J. Y. Li \& Q. Mei: Effect of nimesulide on proliferation and apoptosis of human hepatoma SMMC-7721 cells. World J Gastroenterol, 8, 483-7(2002)

108. Williams, G. T.: Programmed cell death: apoptosis and oncogenesis. Cell, 65, 1097-8(1991)

109. Leng, J., C. Han, A. J. Demetris, G. K. Michalopoulos \& T. Wu: Cyclooxygenase-2 promotes hepatocellular carcinoma cell growth through Akt activation: evidence for Akt inhibition in celecoxib-induced apoptosis. Hepatology, 38, 75668(2003)

110. Liu, F., Y. Song \& D. Liu: Hydrodynamics-based transfection in animals by systemic administration of plasmid DNA. Gene Ther, 6, 1258-66(1999)

Key words: cyclooxygenase, prostanoids, genetically altered animal models

Send correspondence: Marta Casado; Instituto de Biomedicina de Valencia (CSIC) Jaime Roig 11, 46010 Valencia (Spain).

Telf: +34963393778; Fax: +34963690800; Email: mcasado@ibv.csic.es 


\section{FIGURE LEGENDS}

Figure 1. The arachidonic acid cascade: role of the cyclooxygenase in the production of the constitutive and inducible eicosanoids (prostaglandins, thromboxanes and leukotrienes). The primary function of each eicosanoid is shown.

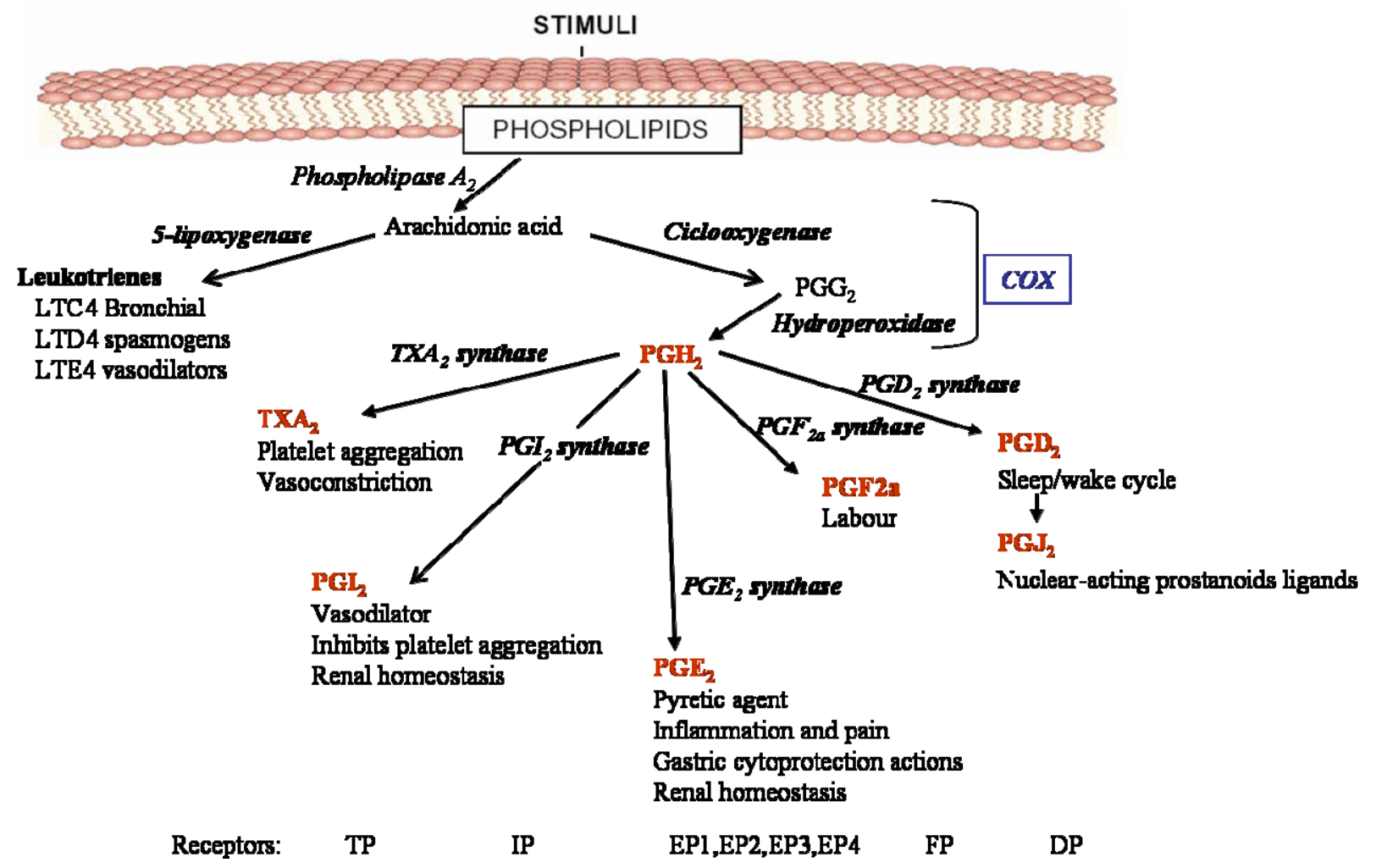


Figure 2. Schematic diagrams of transgenic (panel A) or gene-targeting (panel B) approaches for stable modification of the mouse genome.
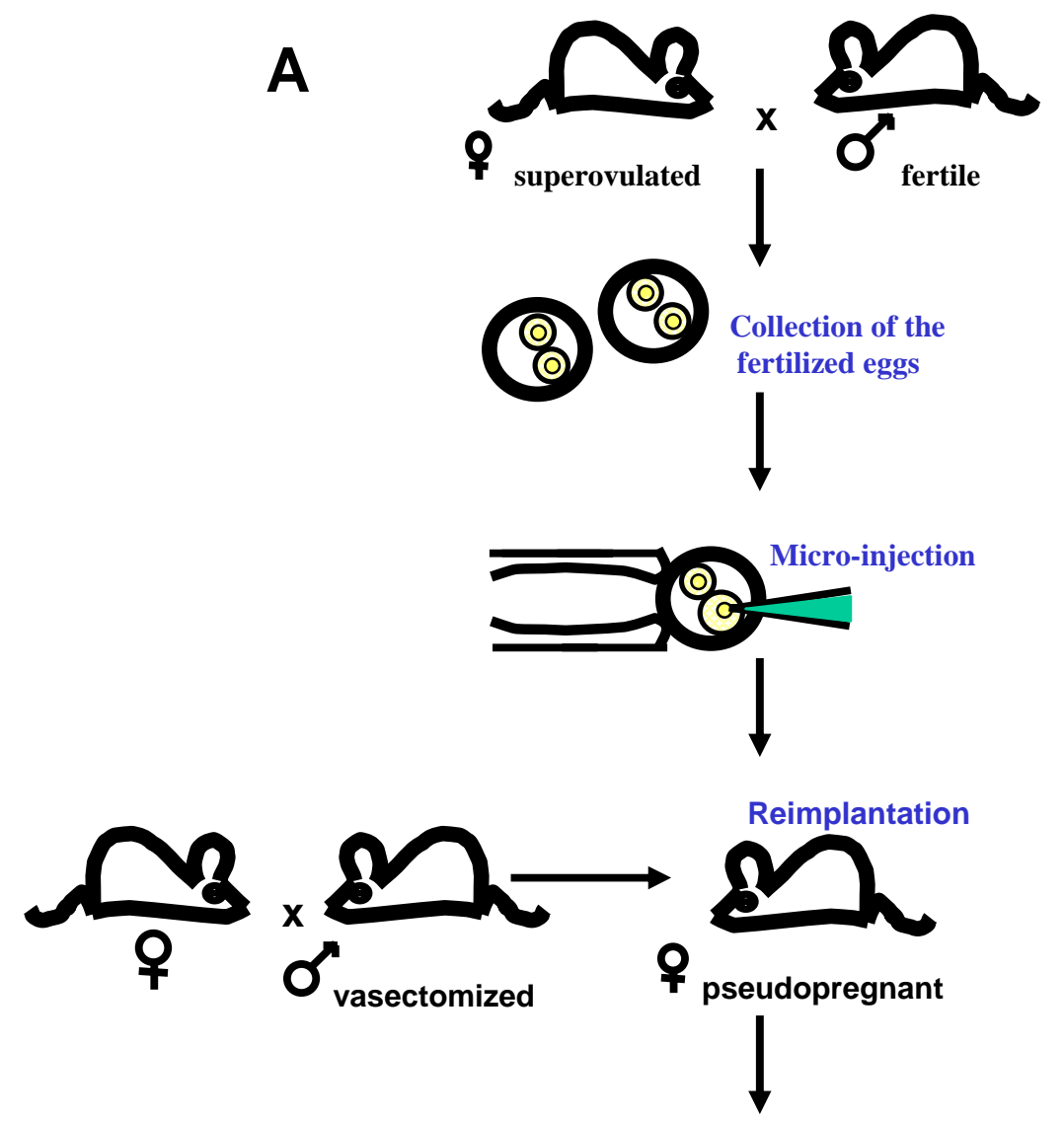

birth

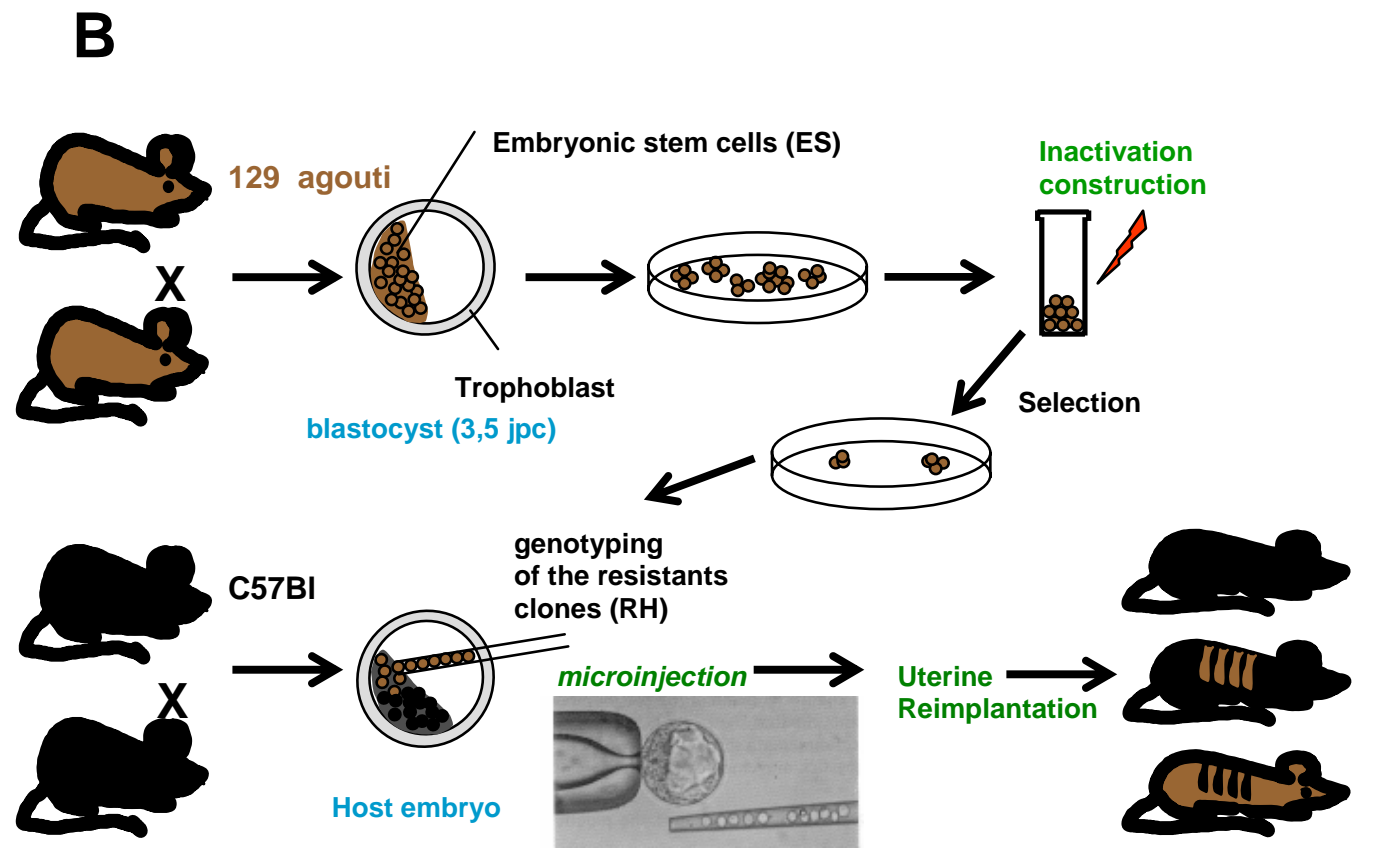

Chimeric mice 
Figure 3. Physiological significance of COX-2 expression after PH showed alterations in various parameters of cell cycle progression: COX-2 deficient mice (KO) mice exhibited an impaired incorporation of $\left[{ }^{3} \mathrm{H}\right]$ thymidine into hepatocyte nuclei at 48h after PH (radioactive nuclei appear yellow) and, in agreement with these results, the levels of PCNA, a marker of S phase, were $65 \%$ lower in the $\mathrm{KO}$ mice compared with the wild-type littermates.
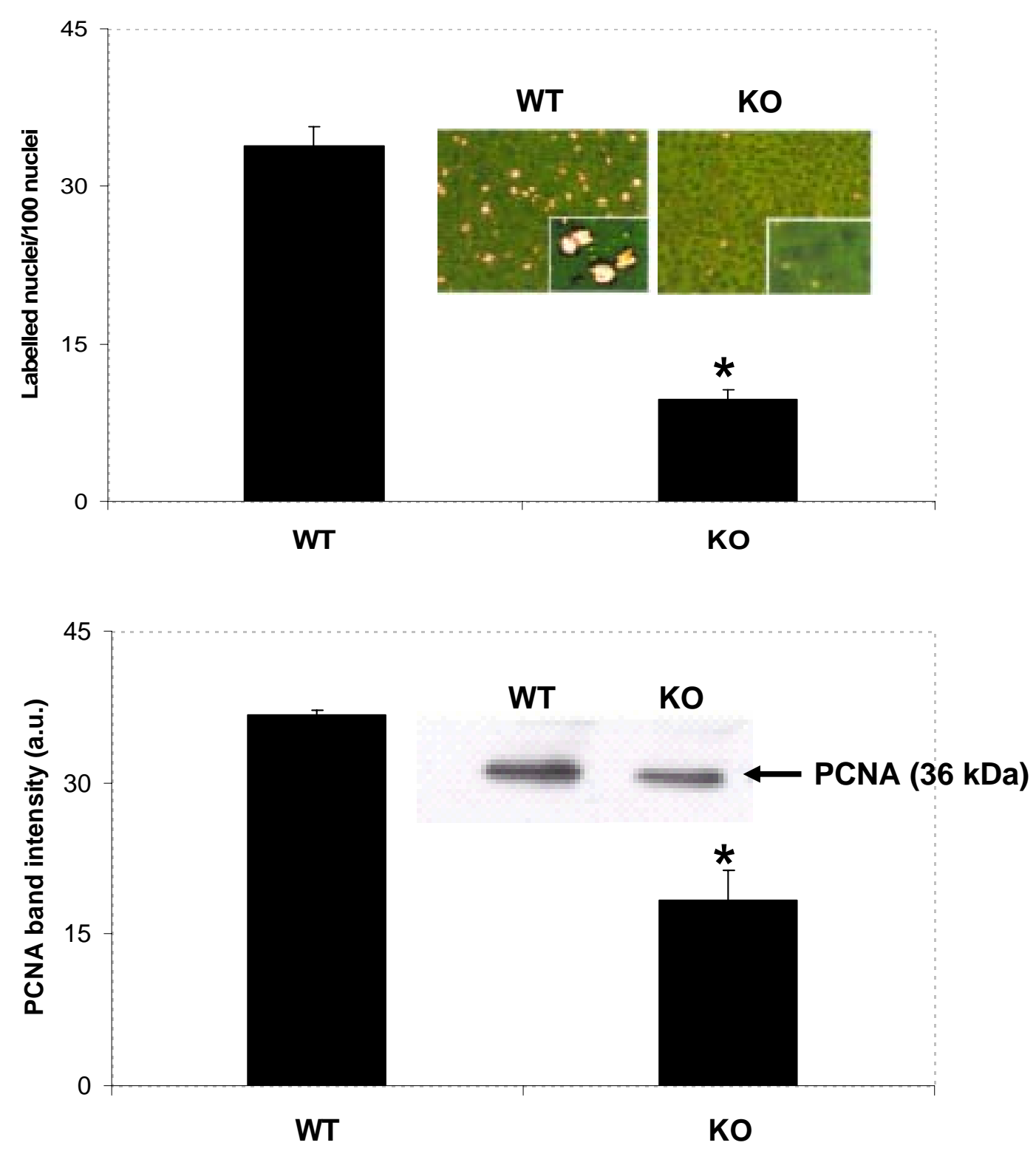
Table 1. Characteristics of COX-2 genetically altered mouse.

\begin{tabular}{|c|c|c|}
\hline Pathophysiological Process & Transgenic mice & COX-2 deficient mice \\
\hline Neonatal mortality & & Increased $(25,26,27)$ \\
\hline Adult mortality & & Increased (25) \\
\hline Patent ductus arteriosus & & Increased (27) \\
\hline Postnatal kidney development & & Impaired $(25,26,32)$ \\
\hline Renal homeostasis functions & & Altered $(36,37,38)$ \\
\hline Ovulation/Implantation/Decidualization & & Impaired $(41,42)$ \\
\hline Mucosal integrity & & Normal (24) \\
\hline Neuronal injury & Increased (22) & Increased $(51,52,53)$ \\
\hline Cognitive deficits & Age-dependent (56) & \\
\hline Cardiac fibrosis & & Increased (26) \\
\hline Liver regeneration & & Altered (74) \\
\hline Inflammation & & Altered (79) \\
\hline Intestinal tumorigenesis & Increased (20) & Decreased (88) \\
\hline Mammary gland & Metastatic tumors $(21,96)$ & \\
\hline $\begin{array}{l}\text { Morphogenesis and number of hair } \\
\text { follicles }\end{array}$ & Altered (alopecia) (98) & \\
\hline Sebaceous glands & Hyperplasia (23) & \\
\hline Skin tumors & $\begin{array}{l}\text { Increased in response of carcinogens } \\
\text { (99) }\end{array}$ & Reduced $(101,102)$ \\
\hline Liver apoptosis & & Protected (unpublished data) \\
\hline
\end{tabular}

